\title{
Teaching and Learning in Further Education: the Ofsted factor
}

The Further Education (FE) sector in the UK, or post compulsory education as it is often referred to, has undergone some radical changes in recent years. Historically FE is synonymous with vocational education and training, providing communities with courses that tended to be practical, non-academic subjects. Many FE lecturers came from industries such as construction and engineering and they were vital in providing the subject knowledge needed by colleges to enable them to offer a wide provision of courses. However, FE had not undergone the regime of teacher qualifications, regulation and inspection to the extent that schools had. In 2001, the New Labour Government began a series of reforms that would overhaul post compulsory education with the objective of making the sector more effective, and thereby meeting the wider objective of creating a more productive workforce. One of the many reforms was to introduce a system of inspection by placing FE into Ofsted's remit. The new reform prompted FE colleges to, for the first time, implement their own institutional policies of observing teaching and learning (OTL) in order to prepare for impending inspection by Ofsted. This paper examines the implementation of the policy of OTL, with focus on one college of further education, and scrutinises its effects on the sector.

Keywords: Further Education; post-compulsory education; lesson observation; professional development; Ofsted

\section{Introduction}

When New Labour won the election in 1997, one of the overarching objectives high on the agenda was to improve quality and raise standards in education. This, it was argued, would create an effective and skilled workforce, capable of competing in the global market, and keeping the country economically prosperous. The focus on skills and workforce meant that the post-16 sector of education, also known as Further Education (FE), would be subject to reform. In the foreword of the first white paper proposing changes to post-16 learning, the then Secretary of State, David Blunkett, stated 'The skill needs of the future will be different from those of today and it is clear that we will not keep pace with the modern economies of our competitors if we are unable to match today's skills with the challenge of the developing information and communication age of tomorrow' (DfEE, 1999: 3). Thereafter ensued a number of educational policies, some aimed at improving the quality of teaching and learning by raising standards in the post-16 sector. 
One of these policies involved the implementation of a new system concerned with observations of teaching and learning, known in the sector as OTL. Observations of teaching are carried out periodically by post-16 further education institutions in order to check the quality of teaching within the classroom. The observations are often called mock inspections, as Ofsted conduct similar observations during their inspections, and have done in schools for some time. The policy of observing teaching in FE came into practice a decade and a half ago as a result of the New Labour government's drive to raise standards. It is interesting now to take a retrospective look back at how the policy was implemented, what impact it had, and whether the effects have been a positive experience for lecturing staff within the sector. The policy of OTL, in comparison to some educational reforms, has had a relatively short existence so far but its presence has very much been felt at every level within FE as it has weaved its way into lecturers' and managers' lives, making an impact on careers, classroom practice and, for some, a decision on whether to remain in the sector. One of the issues raised in this article is that the policy causes lecturers a considerable amount of stress, which, in turn, serves to reinforce negative attitudes towards lesson observations when, in fact, observations should be a beneficial and career enhancing experience.

The overall objective of this article is to critically examine the policy of OTL within the sector of FE, and in particular from the perspective of one college of further education, and how this institution has constructed and implemented its own policy of observations of teaching and learning. The first section, the global context, examines the international forces that have driven this policy to be implemented on a local level. The second section, the national context, looks closely at what action the government took in order to meet their overarching objective of competing in the global market. The third section, the local context, overviews how the policy works on an institutional level. Whilst the final section is a critical examination of one educational institution, and how this institution constructed and implemented its own policy of observations of teaching and learning. By examining the institution, we can gain an insight into how this new practice was implemented, the levers that were used to implement the policy, and to some extent, the impact these have had on the lecturing staff. This is a particularly important point because, as lecturers are at the 'ground level' of teaching, it is they who would be most affected - as I have already 
stated: an impact on careers, classroom practice and, for some, a decision on whether to remain in the sector, all stem from implementation of the OTL policy. The institution, which will be known as Norton College for anonymity, is a College of Further Education in the south east of England.

Norton College of Further Education is the institution where I began my career. I remained in their employment between 2001 and 2012 when, having become a doctoral student, I moved my career into Higher Education. When I started work at Norton I was a newly qualified lecturer. The OTL policy was implemented in 2003. Over the following nine years I progressed up the promotions ladder to team leader and then to curriculum manager, before leaving FE for HE. I therefore experienced the policy at various levels within the sector. A recent announcement suggested that Ofsted were going to cease lesson observations from September 2014 during FE inspections (Stigger, 2014), and this will relieve a certain amount of pressure for many. However, that is not to say that lesson observations will cease on an institutional level, and nor should they. In the conclusion, I argue that, since raising the school leaving age, there is now more need than ever for FE lecturers to be on a par with teachers. However, the regime needs to be implemented differently. The current system of OTL could be overhauled and carried out in a more supportive, effective and collaborative way.

\section{The Global Context}

When New Labour took power, the education system was high on the agenda and subject to reform. As Coffield et al. asserted: 'we have a history of under-investment in training and a long tale of underachievement at school' (2008: 3). The government intended to build an effective and skilled workforce that was capable of competing within a global market. The Chancellor of the time, Gordon Brown, in the white paper Further Education: raising skills, improving life chances, stated: 'Our economic future depends on our productivity as a nation. That requires a labour force with skills to match the best in the world' (DfEE, 2006: 1). Economic performance within a competitive global market was one of the major aims, and therefore the driver behind the education reform. This, it was argued, could only be achieved by starting with education and its reform; widening participation, raising standards, improving quality, 
and overall creating a more effective system to ensure the country remained economically prosperous.

The concept of investing in education in order to achieve economic prosperity through a skilled workforce is known as Human Capital Theory (HCT). HCT first emerged in the 1960s; Olssen (2004) cited Schultz (1960) as stating 'I propose to treat education as an investment in man and to treat its consequences as a form of capital...I shall refer to it as human capital...it renders a productive service of value to the economy' (p. 147). HCT works on two levels: the personal and the social. The personal level is said to accrue a private rate of return. This benefits the individual as they invest in their own education in order to increase their earning power. If the cost of an individual's education is offset against long term higher earnings, then it can be considered to be an investment. However, the social level operates on a national scale, and education is seen as an overall good for the country. Olssen asserted that 'Education as a public good is seen in a number of ways, including the potential to develop the moral, ethical, social, cultural and political awareness of all citizens, as well as to assist in the effective operation of the democratic process' (2004: 148). Olssen also emphasised the connection between skills and productivity: 'workforce and management skills are seen as essential determinants of national economic performance' (2004: 150). Therefore, there was a strong case for raising standards in post-16 education, the sector where these skills are taught, and this, stated the government, is how they will eventually match the competitiveness needed in the global market.

The first white paper from the government, published sixty seven days after taking office, stated 'We are talking about investing in human capital in an age of knowledge. To compete in the global economy' (DfEE, 1997: 3). Ball made an interesting discovery when he commented on the use of the word 'standards' in education related articles in 1998 as occurring '2,272 times' (2008: 113). However, this was not merely spin or the use of a buzzword; the government had radical plans and intentions. Writing in 2008, Coffield et al. noted that 'the Labour government had devoted more time, energy and resources to the learning and skills sector (LSS) ${ }^{1}$ than has any previous administration' ( $p$ 3). LSS was the sector where, not only a

\footnotetext{
${ }^{1}$ Created in 1999, the LSS would be the new educational sector in the UK encompassing all post-16 education and training, except Higher Education.
} 
large proportion of adult learners acquired their skills; it was also the area of education that had been underperforming, and to an extent neglected and overlooked. Foster's perception of further education was as the 'disadvantaged middle child between schools and higher education' (2005: 5-6); Foster also proposed that the unique core focus of FE should be in skill building for the economy' (ibid). However, Foster's comment places a huge burden on the further education sector as it implies that colleges of FE are wholly responsible for equipping all post-16 learners with skills, when there are many more institutions that train post-16 learners. In addition, part of the further education sector's role is for progression; many learners progress from further to higher education to complete undergraduate programmes.

Ball highlighted a further issue within the sector by commenting on retention and drop-out rates in comparison to global competitors: 'In terms of western European and $\mathrm{OECD}^{2}$ comparators, England performs poorly in respect to retention in post 16 [education]' (2008: 113). Therefore, it could be argued that raising standards of education within the sector would not only improve retention but would also improve performance, acquisition of skills, and contribute towards creating a more effective future workforce, as well as progressing learners to a higher level of academic study, if that is their chosen route.

In its 1999 white paper Learning to Succeed: a new framework for post 16 learning, the government explained its vision, and how raising standards in this sector would ultimately make the country more economically competitive. They start by outlining the challenge, and how 'equipping individuals, employers and the country to meet the demands of the $21^{\text {st }}$ century is immense and immediate' (DfEE, 1999: 12). They go on to address the scale of the challenge:

Productivity in the UK is lower than in other major countries. The Gross Domestic Product per worker in the UK lags behind the US by almost $40 \%$ and behind France and Germany by around 20\%...in 1998 the proportion of adults in the UK with qualifications at technician level and above was still only half that of Germany...the proportion of UK adults with qualifications at intermediate level and above is well below that of France (ibid).

\footnotetext{
${ }^{2}$ the Organisation for Economic Cooperation and Development
} 
The government also acknowledged that a lack of qualifications and skills will have a direct effect on the effectiveness of the workforce: 'There are too many people with few, if any, qualifications and too many with low skills. Lack of skills reduces people's chances of well- paid and steady employment. Those without qualifications earn $30 \%$ less than average earnings' (ibid). The government aimed to break the 'cycle of deprivation and disadvantage' (DfEE, 1999: 16) by raising standards in teaching, improving the quality of post-16 education, equipping people with more skills and qualifications, enabling them to take up better paid positions in the workforce, and ultimately improving the economic prosperity of the country.

Historically, post compulsory education within England had been ignored in comparison to mainstream schools and higher education. Interestingly, Coffield et al. commented on 'a world which remains invisible to most politicians, academics and commentators because, with very few exceptions, neither they nor their children have ever passed through it' (2008: 4). Schools had traditionally been regulated, inspected, and the national curriculum firmly established. Higher education has always been seen as the sector of prestige, highly academic and with the most prestigious universities carrying royal seal. The post compulsory sector on the other hand had been 'underfunded and under-recognised... at a time when schoolteachers' pay and conditions had been improved, very little had been done to ensure that FE teachers enjoyed the same status or that they were entitled to training in the same way as schoolteachers' (Coles, 2004: 37). However, things were set to improve for the sector; writing in 2005, Gleeson et al. described FE as 'No longer marginalised between school and higher education, FE has become part of a seamless policy web, connecting schooling, higher education and work related learning...' ( $p$ 448). Improving quality and raising standards also meant improving teacher training within the sector; how else would the government ensure that learners would be trained and skilled to the standards required in order to compete effectively in the global market?

The government quickly realised that in order to build an effective workforce, equipped with skills and trained to a high standard, the post compulsory sector of education would need some serious attention paid to it (DfEE, 1999; DfEE, 2006). One of the first educational reforms was the amalgamation of all post compulsory education into a new sector to be known as The Learning and Skills Sector (LSS). 
Post compulsory education in the UK contains a highly diverse range of learners and covers a wide range of institutions delivering post 16 curricula, with the exception of Higher Education. Institutions such as colleges of Further Education Colleges (FECs), Sixth Form colleges, Adult and Community Learning, and Work Based Learning all 'fell within the remit of the new Learning and Skills Sector' (Ewens, 2001: 10). Henceforth, a number of educational policies sprang into practice, some aimed at the new sector, and with particular focus on improving standards in order to cope with global competition and demand. The Learning and Skills Act (DfEE, 2000) established the Learning and Skills Council; The Children's Act (DfES, 2004) enforced the policy Every Child Matters; The Education Act (DfES, 2005) was mostly concerned with changes to the inspection regime, and this was to include the post 16 sector.

Hamilton asserted that 'National policy is rarely driven in isolation from the pressures and discourses emanating from international agencies...think tanks such as the Organisation for Economic Cooperation and Development are actively involved in shaping national policies, particularly through the assembling and publication of international league tables to which national governments have to respond' (2007: 253). It seems that international agencies are the policy drivers to which national governments have to act. Coffield noted 'We are currently the fifth biggest economy in the world, having already been overtaken by China; and within the space of a few years we are going to be overtaken by India as well' (2008: 3). Coffield also posed an interesting question to this fact: "how well placed are we to meet this challenge, particularly if these countries pay low wages for the production of high quality goods and services?' (ibid). Hamilton also said 'the European Union is immensely influential in shaping the terms of debate and has been a significant force in the funding available for the sector already over several decades' (2007: 253). The government would be concentrating on getting the most from that funding by creating what it hoped would be the best quality and most effective post compulsory education from its new Learning and Skills Sector.

\section{The National Context}


After the amalgamation of all post compulsory education providers in the UK into the new LSS, the government took two more radical reforms. Firstly, the Learning and Skills Council (LSC) was commissioned; as a new educational quango, it was given the power to plan, fund and regulate all post compulsory education and training, with the exception of higher education. Coffield (2008) described the LSC:

...from its inception, the government had very high expectations of the new organisation and of the whole sector. In a twenty page remit letter to the LSC in November 2000, David Blunkett, the Secretary of State, charged the new body with drawing up a strategy both to meet the post-16 national learning targets and to enhance equal opportunities. He also added four wider objectives: to encourage young people to stay on in learning; to increase demand for learning by adults; to maximise the contribution of education and training to economic performance; and to raise standards (p. 7).

In order to raise standards and improve the quality of teaching in the classroom, the government decided to introduce qualifications for teachers, and a system of inspection for further education. This new system would be one of the levers used to implement policies of reform. Standards would need to be observed, measured and improved, and this involved the second radical reform. In 2002 Ofsted and the Adult Learning Inspectorate (ALI) merged forces. With Ofsted's long history and experience of inspection in schools, coupled with ALl's specialised knowledge of adult learners, it was thought that the merger would provide the ideal department to oversee the new expected standards in the LSS, and report them back to the LSC, who now had power over all post compulsory education and training, and its funding. However, one of the main concerns was 'the difference in ethos between the two organisations and the dominance of the former in the newly merged structure' (Coffield, 2008: 75). Ofsted had traditionally been the inspectorate of mainstream schools, whereas ALI, the lesser known inspectorate, played a minor role in inspecting adult learning provision. Of the two inspectorates, Ofsted was the dominant force; teaching staff within the LSS were anxious that Ofsted would apply their strategies for inspecting schools onto a very different education system. In comparison to mainstream education, the LSS encompassed different curricula, learners, lecturers, and teaching methods. Learners in the LSS were adults, not children, and teaching took a different approach to that used in schools. 
In 2003, the introduction of the policy mandating observations of teaching and learning to the post compulsory sector classroom was implemented. Initially, the Ofsted system used for inspection, which was part of the Common Inspection Framework, was based on a scale of seven grades ranging from excellent to very poor (ALI/ES/LSC/Ofsted, 2001: 10); this was later reduced to four grades: 1 outstanding; 2 good; 3 satisfactory; 4 inadequate. The criteria for assessing observations was wide ranging and included criterion such as teaching resources used in the classroom (ibid). However, Gleeson et al. (2015) argue that 'Teachers are encouraged to tailor what they do in the classroom during their graded observations to ensure that they comply with prescribed notions of 'good' or 'outstanding' practice, notions that are largely determined though not explicitly defined by Ofsted' (p. 83). This same inspection system would be used to observe and grade a range of areas within the LSS, including teaching and learning. The LSC directed all providers of post compulsory education and training to implement systems and policies of observation of teaching and learning (OTL) within their own institutions. These institutional systems would be used to observe teaching and learning, feed data back to the LSC, and for the LSC to measure and quantify the standards and quality of teaching in the classroom. In addition, the local policies would serve to prepare for Ofsted inspection. This was how the wider objective of raising standards would be met. Ewens, a teacher trainer in the post compulsory sector, provided a section in his teacher trainee handbook that explains policies of OTL, possibly in an effort to enable the trainee to see the larger context of why lesson observations take place:

Quality is inextricably linked with funding. Consistently good quality teaching and learning will be rewarded by LSCs... satisfactory provision will trigger support in devising improvement strategies. Unsatisfactory provision may ultimately mean sanctions. OTL is therefore not just about proof of quality but also about delivering continuous improvement (Ewens, 2001: 2).

Funding, therefore, was one of the policy levers that the LSC used to attract post compulsory education providers to adopt and implement their own policies of OTL. The LSC was abolished in 2010 and replaced, under the new coalition government, by the Skills Funding Agency and the Education Funding Agency, both of whom now act jointly in providing FE colleges with their funding. We have yet to know, since the general election, whether a new agency responsible for funding FE, will emerge. 


\section{The Local Context}

Norton is an inner London college of further education. It is one of the many providers of post compulsory education that became part of the Learning and Skills Sector after New Labour took power. Norton is one of the larger UK providers with 600 lecturing staff and 20,000 learners. The college delivers a wide and varied range of courses, both vocational and academic, including the 14-19 qualifications framework. This framework, which is part of the 14-19 education reform, includes revised GCSEs, A Levels, and the introduction of the new three tier Diploma in secondary schools and colleges, and enables colleges to provide for learners aged 14 and over.

In response to the government's reforms, the LSC powerhouse, and the common inspection framework, all having been imposed in quick succession, Norton set about constructing and implementing its own policy of OTL. They began by establishing a team of professional learning advisors whose job it was to observe teaching and learning within the college. This scheme would be the method that this provider would use in order to raise the quality and improve standards of teaching in its classrooms. In 2003, Norton produced and distributed a comprehensive document that was an overview of the scheme, detailing how OTL would be implemented, and what the lecturing staff were to expect. This was to be Norton's college policy on observation of teaching and learning. All lecturing staff of the college were expected to read and adhere to the policy from that day forward. Norton College took its new duties towards raising standards of teaching and learning very seriously and met with its responsibilities with rigour.

Armitage et al. noted that 'teaching observation provides excellent opportunities for $\mathrm{CPD}$, and yet it can still be seen as a threatening experience. Traditionally teachers have enjoyed a degree of professional autonomy and there is still a strong proprietorial feeling among many about teaching students in their own classroom' (2007: 46-47). Never before, in the history of post compulsory education, had there been a structured and formal system of OTL; it was not part of the FE teaching culture. In the past, there had been mentoring schemes, informal observations from peers, and initial teacher training lesson observations but never such a formal 
system of observations with grading, training and development, and possibly sanctions if grades were inadequate. The new policy was radical and to some, shocking. O'Leary asserted that 'observations are potentially a very unnerving and anxious experience for us. They cause teachers a considerable amount of stress, which, in turn, only serves to reinforce existing negative attitudes to observation on behalf of the teacher' (2006: 196). Some of the stress that O'Leary alludes to is caused by the deficit approach to observing teaching. This approach is based on the assumption that there is something wrong and needs to be corrected. O'Leary explains: 'difficult for even the most confident of teachers to maintain a high level of self-esteem when the current approach to observation adopted by Ofsted inspections is that of a deficit model. Such a model pre-supposes that there is already something missing in the teacher's performance and it is the role of inspector/observer to provide these missing pieces' (2006: 197).

However, up until this point, very little had been done to monitor and regulate standards of teaching in the post compulsory sector, as it had been done in schools; 'reports also revealed that many young people and adults in the sector were not always being taught by appropriately experienced and qualified practitioners' (Coles, 2004: 37). The time had come where there was a need for a new system that included inspection, observation, and feedback. Coles went on to comment that 'consequently, steps were taken to improve the training and practice of FE teachers by surveying their teaching and inspecting it against national criteria in order to improve the quality of classroom practice' (ibid). The University and College Union (UCU) expressed its support and interest with providers' policies on OTL by stating that:

The union is concerned that classroom observation is a fair, valid and reliable process that does not focus solely on the lecturer's competence, but takes into account the totality of the learning experience, the environment and the context in which it takes place. The focus should be on resources available, generic skills and competencies, and not on individual performance (UCU, 2011).

Coffield et al. commented on the design of the policy and asserted that 'those who struggle to make the policy reforms work and know most about how they impact on practice are excluded from their evaluation and redesign' (2007: 738). Lecturers are rarely consulted or surveyed on the implementation of policies, or reforms, and their 
effectiveness. Many lecturers would favour being more involved with policy making, especially at the consultation stage, as they are the 'ground level' workers, and ultimately effecting the changes that the policies are designed to bring about. At Norton, there was to be a complete faculty devoted to raising standards and improving the quality of teaching. Within this faculty, and amongst the other staff, there would be a team of five specialist observers, contracted to conduct lesson observations using the common inspection framework. The team were to observe, grade, feedback, support, and, if appropriate, prescribe teacher training and development in order to raise the standard of teaching in the classroom. This, it was hoped, would also improve the quality of learning, as well as increase retention and achievement rates. The white paper Learning to Succeed asserted that 'We need a major drive to raise standards in post-16 provision as we have done in schools' (DfEE, 1999: 43); Steer et al. commented on this statement: 'Inspection has been seen as an important lever for driving this improvement in standards' (2007: 183).

\section{Policy Levers at Norton College}

In considering the impact of policy on teaching staff, Edward et al. commented that 'teaching staff may be seen as the last link in the policy chain, the ultimate implementers whose behaviour they seek to change, if the experience of learners is to change' (Edward et al., 2007: 158). Norton College's policy of OTL sought to change the behaviour of its lecturing staff by levering them to conform to the policy and its system of classroom observations. One of the strategies used in the policy was to assert the importance of support and development of the lecturing staff. The policy referred to the team of observers who were employed to, amongst other duties, support and advise lecturers, to deliver training, and to share good practice amongst qualified and experienced teachers. The policy promoted supporting and improving the individual teacher's abilities in planning and delivering teaching and learning. The policy also stressed that the OTL scheme is not an inspection or a mock inspection of lecturers' classroom teaching but that it is a 'continuous process of evaluation and support...focussed on the continuing professional development needs of teachers, and the underpinning assumption is that all teachers can benefit from objective observation and professional support and development' (Anon 2005). 
The policy was also keen to stress that the scheme was not punitive, and not being used to simply identify poor teaching, but to enable lecturers' continuing professional development.

Norton wanted its lecturing staff to accept that raising the standards of teaching was as much for their benefit as for anyone else's. Lecturers hold their professional credibility in high esteem; being knowledgeable, qualified, and able to prove one's skills as a teacher through the use of such a scheme is appealing. Cockburn stated that 'Those teachers who see the value of observation celebrate its potentiality for improving the educational experience of learners and their own professional lives' (2005: 374). Cockburn is highlighting two major benefits of the policy of OTL: not only does it contribute to the lecturer's own professional credibility, it can also enhance the experience of the learner. Both of these benefits are considerable in meeting the ultimate objective of raising standards in the classroom. Cockburn goes on to assert how implementing a policy of observation can be achieved from a positive and productive perspective, depending on how the institution sells it to its employees: 'If the observation of teaching and learning is only associated with inspection, appraisal or evaluation, it is not surprising anxiety is commonly associated with the process. However, if it is perceived in an open-minded, collaborative and non-defensive spirit, and construed as a valuable developmental exercise, its appeal will be heightened' (ibid). Norton was keen for its lecturers to perceive the OTL scheme as a collaborative and developmental exercise, and this is evident in the policy discourse.

When Norton introduced its policy of OTL, the institution decided to use the grading system from the Ofsted common inspection framework (Ofsted, 2012). The four grades and their descriptors would be used to make a judgement about the quality of teaching in the classroom, as well as the presence and quality of lesson plans, schemes of work, teaching resources, and the learners' experiences. The observation grade would be recorded confidentially under the lecturer's name, and also would be collated anonymously along with all other lecturers' observation grades into a report for the LSC. This information, alongside other quality related data such as recruitment targets and performance indicators would be used by the LSC to make decisions concerning funding. It is therefore in all institutions' own interests to use effective levers when implementing their policy of OTL as their 
funding may depend on them. As Ewens has stated 'Quality is inextricably linked with funding' (2001: 2), and one of the ways that colleges demonstrated quality was through OTL data. O'Leary commented that '....many colleges tend to adopt a "restricted approach" to the use of OTL. This is typified by their reliance on the use of the Ofsted four-point graded scale to measure performance and prioritising the needs of performance-management systems over those of their staff' (2012: 16). Gleeson noted that 'the downward pressure of audit, funding and managerial reform has generated regulatory regimes...' (Crowley, 2014: 26). However, these regulatory regimes resulted in what O'Leary refers to as the 'showcase lesson' (Gleeson et al.,: 2015), the lesson reserved and enacted for the purposes of inspection.

Norton stated in its OTL policy that 'a teacher will be observed as many times as necessary to enable the teacher to plan and deliver learning to the minimum acceptable standard of Ofsted grade 3' (Anon 2005). The college's target was that all lessons should be within the range of grades 1-3; this was the accepted standard of quality. What Norton did not include in the staff version of the policy that outlined the outcomes of observation grades was additional information on how the institution planned on eliminating unsatisfactory teaching. Norton College used extremely effective levers, or as Kooiman explains 'instruments chosen to meet particular political aims' (2003: 45); the institution awarded a $£ 500$ incentive bonus for a grade 1 lesson observation, and a grade 4 could have led to dismissal of the teacher from their post. This was Norton's approach to maximising funding that would be awarded on the basis of data collected from observing teaching. Smith and O'Leary (2013) coined the term 'managerialist positivism' where the 'complexity of the teaching and learning process is superficially reduced to the presentation of quantitative performance data' (Gleeson et al.,: 2015). However, if this final column of data is used to make decisions about funding, it is crucial.

These particular levers may seem unnecessary and extreme, especially given that Norton's policy of OTL referred to 'assisting teachers in the development of teaching skills and continuing professional developmental needs of teachers' (Anon 2005), and other rhetoric used in the policy in order to heighten the appeal of the scheme to lecturing staff. However, levers such as these used on a local level are on a par with levers used on a national level such as those used by the LSC, and even an international level, such as those used by the EU. For example, earlier Ewens was 
quoted as stating that 'Quality is inextricably linked with funding. Consistently good quality teaching and learning will be rewarded by LSCs... satisfactory provision will trigger support in devising improvement strategies. Unsatisfactory provision may ultimately mean sanctions' (2001: 2). Earlier still, Hamilton was quoted as commenting that 'the European Union is immensely influential in shaping the terms of debate and has been a significant force in the funding available for the sector... the OECD are actively involved in shaping national policies, particularly through the assembling and publication of international league tables' (2007: 253). Interestingly, Hamilton also notes how 'policy-borrowing is a constant feature of educational policy' (ibid). The use of similar levers on various levels can be tracked through policy trajectory, or the evolution of a wider policy, from an international level down to the institutional or even the classroom level of the learners. Norton's policy and the levers they used to implement it may well have been 'borrowed' from higher level policy implementation.

It is interesting to observe how policy filters down through the levels and how it is practised at each one. Coffield et al., who have identified eleven different levels within the LSS: 1 being the international level; 7 being the institutional level; 11 being the learners, note how 'Each level contributes to understanding the ways in which policy percolates down to practice' (2007: 726). However, this is not to assume that institutions on each level are practising as the policy-makers intended. Edward et al. criticise how 'institutions can be seen to translate government policy into systems of implementation that suit their local or administrative needs, which may or may not reflect accurately the intentions of those who designed the policy' (2007: 156). This did not seem to be the case at Norton; their policy of OTL seemed to have been implemented in exactly the way government intended. Armitage supports this by stating that 'The Learning and Skills Act (2000) gave Ofsted and ALI the remit to inspect all $\mathrm{PCET}^{3}$. The purpose of inspection is to evaluate the effectiveness and efficiency of an institution...and in order to do this inspectors will concentrate on observing lessons' (2007: 49). Norton simply transferred this principle, and the instruments used to lever it into place, to their level.

\footnotetext{
${ }^{3}$ Post Compulsory Education and Training
} 
In 2012, Ofsted implemented a new common inspection framework for further education (Ofsted, 2012). The four point grading scale for lesson observations has remained and, although Norton has now moved away from this particular system for observing lessons, they now use their own scale, many colleges continue to work with it. The new grading scale has shifted slightly from the old one and now is: 1 outstanding; 2 good; 3 requires improvement; 4 inadequate. Under the previous grading scale, colleges' targets were that all lessons should be within the range of grades 1-3. Under the new grading scale, colleges' targets would be for all lessons to be 1 or 2 . This has tightened the inspection regime and raised the bar; a grade 3 is no longer acceptable. The Lingfield Report (2012) acknowledged the difficulty in changing the grading system and the impact it would have on colleges:

The change in grade descriptions in the latest, 2012, version of the Common Inspection Framework from grade 3 'satisfactory' to grade 3 'requires improvement', is likely to have an impact. For the organisation concerned, a sudden change in the government's view of its quality of service to learners (as represented by Ofsted) is certain to claim a central place in the attentions of the governing board and the senior management team...(p. 35).

A more recent announcement from the Government is that Ofsted are 'going to stop graded lesson observations in colleges as part of a pilot scheme from September 2014' (Stigger, 2014). The news follows a report by the University and College Union (2014) that raised serious questions on whether the practice of grading lessons was fit for purpose. A new report has called into question the widely used practice of graded lesson observation, suggesting it has no discernible impact on the quality of teaching and learning. In the report on their website, UCU described lesson observations as a 'box ticking exercise' (ibid) that is 'a source of increased stress and anxiety' and that 'they were used as a disciplinary stick, through being linked to capability procedures' (ibid). O'Leary (2013) compiled a report for UCU in which he outlines more effective use of lesson observations. He asserts that OTL should be 'professionally enriching' and that 'observation is at its most effective as a form of intervention when it prioritises the growth of tutors' professional learning and skills and empowers them to become active agents in the construction of their own professional identity, learning and development' (p. 9). Norton continues to use the 
lesson observation regime, however they have moved away from the Ofsted fourpoint grade scale and instead use a system that determines if a lesson has met the college's standards.

\section{Conclusion}

It is now almost two decades since New Labour were in power and radically reformed the post compulsory sector into what is now known as the Learning and Skills Sector. Lecturing staff now rarely question institutional policies of OTL, or the national policy of Ofsted inspection. When a trainee lecturer has completed the teacher training for post compulsory education, having had their classroom practice teaching observed, the natural progression is to move into employment with lesson observations carried out by the employer. This can be deemed as a positive, developmental, and career enhancing process, depending on the regime that is in operation.

However, Coffield et al. observed that, in some cases, 'the model is a closed system...[that] treats the workforce as another lever to be pulled rather than as creative and socially committed professionals who should be involved in the formation, enactment, evaluation and redesign of policy' (2008: 37). In addition to this, key findings from O'Leary's report, prepared for the UCU, indicate that the majority of lecturing staff 'disagreed that graded observations were the most effective method of assessing staff competence and performance' (O'Leary, 2013), and this may be because of the way the regime is implemented. Gleeson asserted that the downward pressure of audit, funding and managerial reform has generated regulatory regimes that continue to restrict autonomous leadership and professionalism...' (Crowley, 2014: 26). If a regime restricts autonomous professionalism there will be less creativity and freedom in the classroom, and more staging of what the inspectors/observers want to see; 'inspection can act as a stimulus to improvement but also as a constraint on innovation' (Coffield, et al., 2008: 37).

Nevertheless, standards among lecturing staff in the FE sector ought to be monitored and maintained, especially if those staff desire levels of credibility on a par 
with teachers. In addition, with the school leaving age having been raised to 18 , and many of those learners staying in education by progressing into colleges, there is even more need to monitor the standards of teaching in the classroom. FE is no longer the post-compulsory sector, for some it is very much a part of their compulsory schooling, and deserves rigorous approaches to teaching observation. However, it is clear, both from the literature and my own experiences of Norton College, that the current system of OTL needs to be overhauled and implemented in a more effective and developmental way. O'Leary and Brooks (2014) assert that 'FE has outgrown an assessment system that may have served a purpose at a time when too many staff had no professional training or recognised teaching qualification' (p. 544). They argue that working within a culture of 'assessment as learning' (ibid) is ineffective, unsupportive, and limiting. 'FE has a greater awareness of the principles and practice of continuous improvement in teaching and learning. However, a workplace culture in which this can flourish is needed' (ibid). Only then will we get the best from dedicated lecturing staff within a much needed, and expanding, sector of education.

\section{References}

Allen, W. R., Bonous-Hammarth, M., Teranishi, R. T. (2006) Higher Education in a Global Society: achieving diversity, equity and excellence. Oxford, England: Elsevier Ltd

Anonymous (2005) Improving Teaching and Learning London, England: Author Armitage, A. (2007). Teaching and Training in Post-Compulsory Education. Buckinghamshire, England: Open University Press

Adult Learning Inspectorate/ES/LSC/Ofsted (2001). Raising Standards in Post 16 Learning: self-assessment and development plans. England: ALI/ES/LSC/Ofsted Ball, S. (2008). The Education Debate. Bristol, England: The Policy Press Cockburn, J. (2005). Perspectives and Politics of Classroom Observation, Research in Post-Compulsory Education, 10 (3) pp. 373-388. 
Coffield, F., Edward, S., Finlay, I., Hodgson, A., Spours, K., Steer, R. and Gregson, M. (2007) How policy impacts on practice and how practice does not impact on policy, British Educational Research Journal, 33 (5) pp. 723-741.

Coffield, F., Edward, S., Finlay, I., Hodgson, A., Spours, K. and Steer, R. (2008). Improving Learning, Skills and Inclusion. Oxon, England: Routledge

Coles, A. (2004). Teaching in Post-Compulsory Education. London, England: David Fulton Publishers

Crowley, S. (2014) Challenging Professional Learning London, England: Routledge Department for Education and Employment (DfEE) (1997). Excellence in schools. London, England: HMSO

Department for Education and Employment (DfEE) (1999). Learning to Succeed: a new framework for post 16 learning. London, England: HMSO

Department for Education and Employment (DfEE) (2000) The Learning and Skills Act. London, England: HMSO

Department for Education and Skills (DfES) (2004) The Children's Act. London, England: HMSO

Department for Education and Skills (DfES) ( 2005) The Education Act. London, England: HMSO

Department for Education and Skills (DfES) (2006). Further Education: raising skills, improving life chances. London, England: HMSO

Edward, S., Coffield, F., Steer, R. and Gregson, M. (2007) Endless change in the learning and skills sector: the impact on teaching staff, Journal of Vocational Education and Training, 59 (2) pp. 155-173.

Ewens, D. (2001). Observation of teaching and learning in adult education. London, England: Learning and Skills Development Agency

Foster, A. (2005). Realising the Potential: a review of the future role of further education colleges. London, England: DfES 
Gleeson, D., Davies, J. and Wheeler, E. (2005) On the making and taking of professionalism in the further education workplace, British Journal of Sociology of Education, 26 (4) pp. 445-460.

Gleeson, D., Hughes, J., O' Leary, M. and Smith, R. (2015) The state of professional practice and policy in the English further education system: a view from below, Research in Post-Compulsory Education, 20 (1) pp. 78-95

Hamilton, M. (2007) Reflections on agency and change in the policy process, Journal of Vocational Education and Training, 59 (2) pp. 249-260.

Hodgson, A., Steer, R., Spours, K., Edward, S., Coffield, F., Finlay, I. and Gregson, M. (2007) Learners in the English Learning and Skills Sector: the implications of halfright policy assumptions, Oxford Review of Education, 33 (3) pp. 315-330.

Kooiman, J. (2003). Governing as Governance. London, England: Sage Publications The Lingfield Report (2012) Professionalism in Further Education last accessed 06.03.15 from

https://www.gov.uk/government/uploads/system/uploads/attachment data/file/34641/ 12-1198-professionalism-in-further-education-final.pdf

Ofsted (2014) Handbook for the inspection of further education and skills last accessed 26.10.14 from www.ofsted.gov.uk/resources/handbook-for-inspection-offurther-education-and-skills-september-2012

O' Leary, M. (2006) Can inspectors really improve the quality of teaching in the PCE sector? Classroom observations under the microscope, Research in PostCompulsory Education, 11 (2) pp. 191-198.

O'Leary M. (2012) Time to turn worthless lesson observation into a powerful teaching tool for improving teaching and learning. In Tuition, 4. Last accessed on 20.02.15 from http://www.ifl.ac.uk/media/114829/InTuition-issue-9-Summer-2012.pdf O'Leary (2013) Developing a National Framework for the Effective Use of Lesson Observation in Further Education, Project Report for UCU. Last accessed on 15.03.15 from http://www.ucu.org.uk/media/pdf/i/q/ucu lessonobsproject nov13.pdf 
O'Leary, M. and Brooks, V. (2014) Raising the stakes: classroom observation in the further education sector in England, Professional Development in Education, 40 (4) pp. $530-545$

Olssen, M., Codd, J. and O'Neill, A. (2004) Education Policy: Globalization, Citizenship and Democracy. London, England: Sage Publications

Smith, R. And O'Leary, M. (2013) NPM in an age of austerity: knowledge and experience in Further Education, Journal of Educational Administration and History, 45 (3) pp. 244-266

Steer, R., Spours, K., Hodgson, A., Finlay, I., Coffield, F., Edward, S. and Gregson, M. (2007) 'Modernisation' and the role of policy levers in the learning and skills sector, Journal of Vocational Education and Training, 59 (2) pp. 175-192.

Stigger, J. (The Guardian, Sunday 17 August 2014) Replacing Ofsted would improve the quality of provision in colleges last accessed 26.10.14 from www.theguardian.com/education/2014/aug/17/ofsted-colleges-inspections-peerreview-further-education

UCU (2011) Lesson Observation: UCU Principles \& Position last accessed 20.06.11from www.ucu.org.uk/index.cfm?articleid=2576\#classobs UCU (2014) Damning report calls whole process of lesson observations into question last accessed 06.03.15 from http://www.ucu.org.uk/7105 